\title{
УДК332.012.324: 330.101.541
}

\section{КОРПОРАТИВНИЙ СЕКТОР - ДЖЕРЕЛО ЕКОНОМІЧНОГО ЗРОСТАННЯ УКРАЇНИ}

\author{
Оксана Таранич \\ Донецький наџіональний університет імені Василя Стуса, \\ Вінниия, Украӥна
}

\begin{abstract}
Резюме. Розглянуто особливості розвитку корпоративного сектора як джерела економічного зростання Украӥни в зв 'язку з необхідністю розширеного відтворення та відбудови промисловості краӥни, визначено шляхи та методи залучення цільових інвестицій в умовах системної фінансової та політичної кризи. Визначено, щуо надмірна концентраџія капіталу (олігархізація), корупџія та непрозорість менеджменту державних підприємств визначають дестимулячію розвитку промисловості й споживчого сектора економіки Украӥни, наслідком яких є диспропориійна чисельність середнього класу та значний рівень тіньової економіки. Механізм залучення тіньових коштів до інноваційної відбудови корпоративного сектора є важливим суспільно-політичним урядовим завданням. Проведено огляд особливостей розвитку корпоративного сектора України та визначено, щзо знос основних фондів і структура виробництва не відповідають вимогам щзодо випуску конкурентоспроможної на світовому ринку продукиії. Знос основних фондів практично не дозволяє освоювати виробництво високотехнологічної продукиії; надмірна енергоефективність блокує отримання прибутку для їх відновлення. Доведено ряд умов щодо відтворювального розвитку корпоративного сектора, пов'язаного з інтеграцією банківського капіталу, профільних науково-дослідних інститутів, розвитком механізмів державно-приватного партнерства та субконтрактингу. Визначено иільові підходи до розбудови корпоративного сектора Украӥні, пов'язані з проведенням приватизачї машинобудівних підприємств через відновлення основних фондів; заходів зі зниження рівня тіньової економіки, спрямовані на випуск продукиії з метою імпортозаміщення та високотехнологічного експорту; інтеграції банківського сектора країни з корпоративним сектором та світовим фінансовим ринком.

Ключові слова: корпоративний сектор, економічне зростання, міжнародна конкурентоспроможність підприємств, приватизація, корпоратизація, інновації, технологічні уклади, фондовий ринок.
\end{abstract}

https://doi.org/10.33108/galicianvisnyk_tntu2019.03.031

Отримано 08.05.2019

Постановка проблеми. Економічне зростання країн пов'язано 3 такими чинниками, як циклічність розвитку світового господарства, виробничі можливості країн, НДДКР, урядові ініціативи. 3 них корпоративний сектор України має можливість оперувати виробничими потужностями та розвитком науки й техніки. За умов побудови ефективного державно-приватного партнерства збільшується можливість залучення урядової підтримки до фундаментальних наукових досліджень i розвитку промисловості.

Формування корпоративного сектора України відбувалося шляхом приватизації державних підприємств під час глибокої структурної економічної кризи, відсутності належної ринкової інфраструктури, обтяженості закладами соціальної інфраструктури. Загальний брак обігових коштів підприємств призвів до масової відмови від прикладних досліджень i фінансування проривних інновацій, внаслідок чого сучасний корпоративний сектор України не виконує ролі локомотиву економічного зростання, на відміну від провідних країн світу 
Таким чином, формування умов щодо перетворення корпоративного сектора України у якості важеля технологічного розвитку, джерела концентрації капіталу та розвитку високих технологій є важливим науковим завданням, що передбачатиме зростання міжнародної конкурентоспроможності країни та підвищення якості життя населення.

Аналіз останніх досліджень і публікацій. Пошуку шляхів ефективних форм економічного зростання присвячені дослідження як класиків політичної економії, так i сучасних наукових шкіл неокласицизму, постіндустріалізму, неоіндустріального розвитку. Зокрема, класичним вважається надбання Д. Белла, Дж. Гелбрейта, П. Друкера, Ф. Махлупа, М. Кастельса, М. Пората, Дж. Стігліца, Т. Стоунера, Е. Тоффлера, А. Турена, Ф. Фукуями, Ж. Фурастьє щодо розвитку країн у постіндустріальному суспільстві.

Актуальним питанням розвитку підприємств корпоративного сектора України присвячені публікації таких видатних учених, як Ю. М. Бажал, В. М. Геєць, А. С. Гальчинський, С. Мочерний, В. І. Мунтіян, П. М. Леоненко, В. П. Семиноженко, Ю. Пахомов, С. Соколенко, А. А. Чухно, П. І. Юхименко.

Постановка завдання. Необхідність розширеного відтворення та відбудови промисловості України лягає на підприємства вітчизняного корпоративного сектора та вимагає пошуку шляхів і методів залучення цільових інвестицій, особливо в умовах системної фінансової та політичної кризи.

Метою статті $\epsilon$ визначення підходів до розбудови корпоративного сектора Україні.

Виклад основного матеріалу. Сучасний стан економіки України $є$ транзитивним, що відображає перехід від системи вертикального планового командноадміністративного господарювання до ліберальних ринкових відносин. Також слід зазначити перехід від соціалістичної стратифікації соціуму через капіталістичний двошаровий поділ до постіндустріального тришарового суспільства. Саме ця трансформація є визначальною, що ставить за мету розбудову України як технологічної високорозвиненої країни. Джерелом такого відтворювального розвитку є залучення внутрішніх інвестицій і збалансована система експортно-імпортного товарного балансу.

На заваді відтворювального розвитку України знаходяться як соціальні диспропорції щодо відсутності середнього класу як джерела зниження суспільної соціальної напруженості, так і великого бізнесу як важеля відтворювального розвитку країни. Відбувається розвив доходів між біднішими та багатшими верствами населення, олігархізація промисловості викликає падіння рівня й якості життя населення через накопичення доходів на офшорних рахунках, що не створює ефект мультиплікативного економічного зростання через ініціювання великим бізнесом малих і середніх циклів інноваційного розвитку.

Також негативно впливає на перерозподіл утвореної в країні доданої вартості від'ємний платіжний баланс, який утворюється виробництвом та споживанням промислових товарів, а також нераціональна структура промислових виробництв, що представлена підприємствами другого та переважно третього технологічних укладів, орієнтованих на експорт товарів первинних стадій технологічного перероблення (сировина та напівфабрикати), із низькою доданою вартістю, з яких харчові продукти не є винятком. 
Олігархізацію промисловості України було розпочато з процесів роздержавлення та приватизації, що продовжуються донині шляхом рейдерських захоплень і штучного банкрутства, проте така приватизація не сприяє формуванню ефективного менеджменту. Наявність у промисловості країни містоутворюючих підприємств, вертикально інтегрованих циклів виробництва продукції не завершується технологічним озброєнням, переходом до випуску продукції четвертого-п'ятого технологічних укладів.

Навіть не відбувається оновлення виробничих фондів при середніх показниках зносу 50-70\% за видами економічної діяльності. За таких умов важко прогнозувати залучення зовнішніх інвестицій, реінвестування прибутку, розвиток високих технологій екологічного, енергоефективного спрямування, підвищення міжнародної конкурентоспроможності продукції, розвиток внутрішнього ринку через імпортозаміщення, включення у процеси світового поділу праці.

Створення олігархічних кланів призвело до таких методів протистояння та конкуренції, як політичне лобіювання, використання юридичного, адміністративного, податкового тиску, позазаконного впливу на керівництво незалежних підприємств для зламу управлінського контролю, їх рейдерського захоплення. Такий політикоекономічний розвиток корпоративного сектора призводить до уповільнення технічного прогресу України, зростання рівня «тінізації» економіки, зниження ії ефективності.

Розглянемо рівень розвитку тіньової економіки України за період з 2010 до 2018 рр. за даними Держстату та Мінекономрозвитку України (рис. 1).

Протягом аналізованого періоду відбулося зростання обсягів ВВП у 3,3 раза при загальному зростанні обсягів тіньової економіки у 2,8 раза, що є позитивною тенденцією. Також позитивним фактором є зниження рівня тіньової економіки в Україні за період 3 2014 до 2018 рр. на - 11 в. п. Цей показник є інтегральним, відображає результати розрахунків рівня тіньової економіки за чотирма методами [2]. Так, за трьома 3 них (монетарний, електричний, збитковості підприємств) рівень тіньових відносин за видами економічної діяльності є меншим за інтегральний показник на 4-11 в. п. у 2017 р., а за витратами населення до роздрібного товарообігу вищій на 16 в. п. Відповідно, можна зробити висновок, що відбувається легалізація суспільних відносин у промисловості України за рахунок боротьби з корупцією, яка є головним джерелом виведення з обігу оборотних коштів. Також значним залишається рівень грошових потоків трудових мігрантів, що становив у 2014 р. 58\% до ВВП і скоротився на 10 в. п. на кінець аналізованого періоду (48\% до ВВП).

Таким чином, резервами розвитку промисловості України $є$ комбінування стратегій імпортозаміщення й експортного маркетингу щодо випуску продукції В2B i B2C секторів: побутова техніка, будівельні матеріали, добрива, засоби захисту рослин. Важливим проблемним питанням залишається відсутність внутрішнього виробництва радіотехнічних приладів, іншої машинобудівної продукції на цій технологічній базі. Вхідні фінансові бар'єри перешкоджають розвитку середньому та малому бізнесу в цьому напрямку, тому одним із шляхів є формування державно-приватного партнерства у сфері машинобудування. 


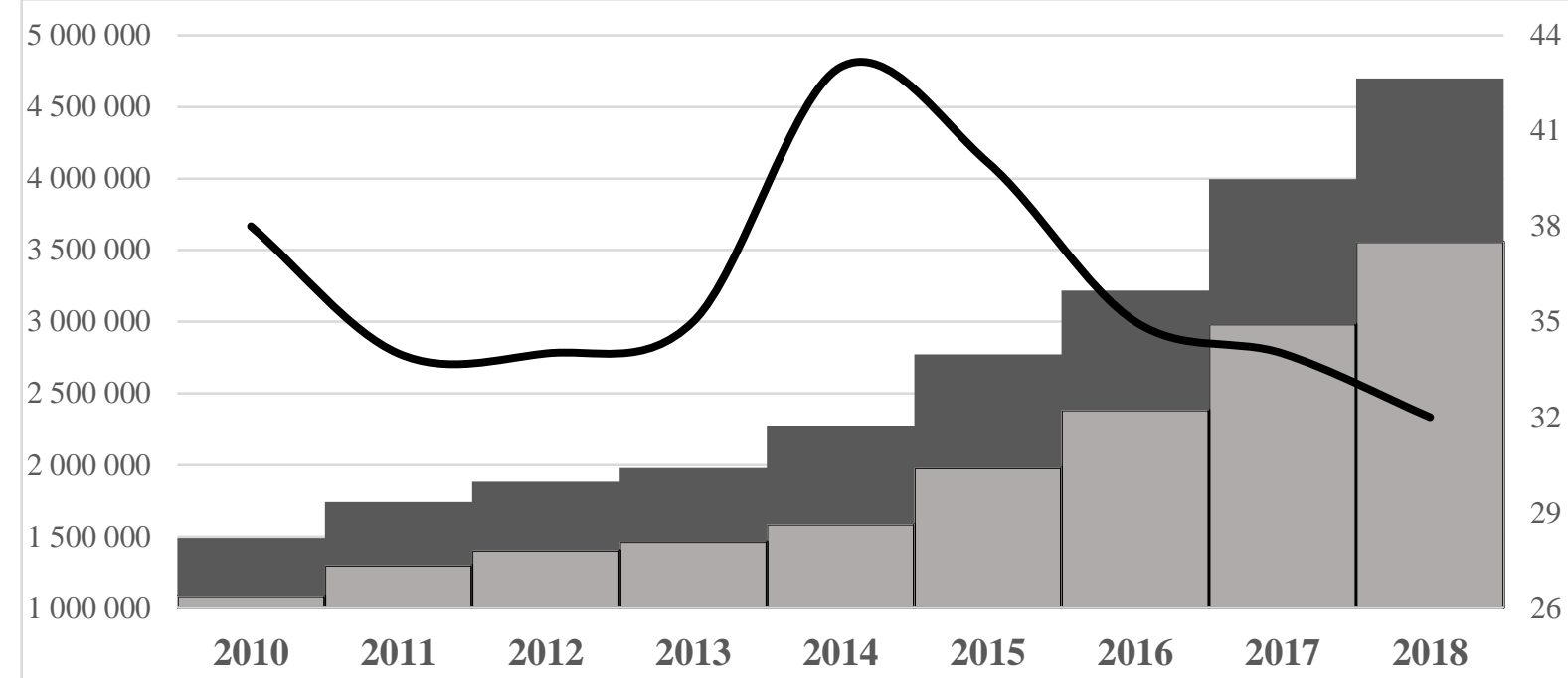

Volume shadow economy, mln. UAH $\square$ GDP, mln. UAH

- Shadow economy level, \%

Рисунок 1. Динаміка зростання ВВП і рівня тіньової економіки України за період з 2010 до 2018 рp.

Figure 1. Dynamics of GDP growth and shadow economy level of Ukraine for the period from 2010 to 2018

Джерело: розраховано автором за даними Держстату та Мінекономрозвитку України $[1,2]$.

Стратегія розвитку державного та корпоративного машинобудування України повинна відштовхуватися від розкриття інформації щодо спеціалізації та кооперації машинобудівних підприємств, прозорості доступу та процедури державних закупівель, відкритості інформаційних потоків, пов'язаних з контролем діяльності менеджерів, управлінням державними корпоративними правами; загальним регулюванням корпоративних відносин, спрямованим на запобігання штучного банкрутства підприємств з наступною приватизацією чи рейдерським захопленням; запобіганням корупції посадових осіб у сфері державних закупівель; підвищенням якості корпоративного менеджменту.

Нині стратегія приватизації державних машинобудівних підприємств повинна сприяти відновленню основних засобів, упровадженню новітніх технологій замість наповнення державного бюджету України. Фінансові результати від приватизації державних підприємств повинні сприяти розвиткові національного фондового ринку, внутрішнього ринку інвестицій, формування сприятливого ринку інвестицій для зовнішніх запозичень.

Для підприємств корпоративного сектора України потрібно мати прозору національну захисну систему проти рейдерських захоплень шляхом відчуження активів через судові позови, викривлення реєстру, порушення при проведенні зборів акціонерів, а також порушення прав акціонерів щодо виплати дивідендів. Формування незалежного професійного топ-менеджменту без участі в акціях підприємств і розподілу прибутку призводить до конфліктів із власниками бізнесу: корпоративна соціальна відповідальність, екологізація виробництва, енергоефективність проти «зарплат у конвертах», виведення прибутків у офшори. 
Іншим важливим аспектом стратегії розвитку корпоративного сектора України $\epsilon$ поєднання існуючих сировинних монополій у технологічні ланцюги виробництва продукції з підвищеною доданою вартістю з метою відмови від експорту сировини та напівфабрикатів, технологічного переозброєння виробництва, залучення вітчизняних підприємств до світових процесів поділу праці, підвищення міжнародної конкурентоспроможності країни.

Сучасний банківський сектор країни має низький ступінь інтеграції 3 корпоративним сектором. Тому із підвищенням міжнародної конкурентоспроможності України та зростанням кредитного рейтингу відбуватиметься вихід вітчизняних підприємств до світового ринку запозичень та фондового ринку як джерела технологічного переозброєння, розвитку виробництв четвертого-п'ятого технологічних укладів. Вже сьогодні необхідно визначитись із приведенням законодавства України до світових стандартів, що передбачатимуть захист прав акціонерів, поширене використання фондового ринку як інструменту активізації інноваційного розвитку підприємств корпоративного сектора, перетворення його на рушійну силу розширеного відтворення, джерела економічного зростання країни.

Також розвиток банківського сектора та фондового ринку України повинні забезпечувати безпечні процеси первинного розміщення акцій акціонерних товариств на внутрішньому та зовнішньому сегментах світового ринку, у т. ч. участь у грантових програмах фінансування фундаментальних і прикладних досліджень, кредитування 3 боку ЕБРР, СБРР, венчурних інвестиційних фондів.

Висновки. Огляд особливостей розвитку корпоративного сектора України дозволив визначити ряд певних умов щодо його відтворювального розвитку, пов'язаного з інтеграцією банківського капіталу, профільних науково-дослідних інститутів, розвитку механізмів державно-приватного партнерства та субконтрактингу.

Визначено такі підходи до розбудови корпоративного сектора України, організаційно-економічні, пов'язані 3 проведенням приватизації машинобудівних підприємств через відновлення основних фондів; заходи зі зниження рівня тіньової економіки, спрямовані на випуск продукції 3 метою імпортозаміщення та високотехнологічного експорту; інтеграції банківського сектора країни з корпоративним сектором та світовим фінансовим ринком.

Conclusions. The review of corporate sector development features in Ukraine allowed defining the row of certain terms in relation to his reproductive development, related to the integration of bank capital, field-oriented research institutes, and development of mechanisms of state-private partnership and subcontracting.

Thus, the following approaches for alteration the corporate sector in Ukraine are defined: as organizationally-economic, related to conducting the privatization of machinebuilding enterprises by the renewal of general funds; actions to decline level of shadow economy, aimed at product issue to substitute import and hi-tech export; integration of bank sector of the country with a corporate sector and world financial market.

\section{Список використаної літератури}

1. Державний комітет статистики України URL: http://www.ukrstat.gov.ua (дата звернення: 08.04.2019).

2. Тенденції тіньової економіки в Україні у січні-вересні 2018 року URL: http://me.gov.ua/ Documents/ List?lang =uk-UA\&id=e384c5a7-6533-4ab6-b56f-50e5243eb15a\&tag = Tendentsii Tinovoi Ekonomiki (дата звернення: 08.04.2019). 


\title{
References
}

1. State Statistics Committee of Ukraine (2019), State Statistics Committee of Ukraine corporate website, URL: www.ukrstat.gov.ua (accessed 8 April 2019).

2. Tendentsiyi tinovoyi ekonomiky v Ukrayini u sichni - veresni 2018 roku. [Trends in the Shadow Economy in Ukraine in January-September 2018] (2019), Ministry of Economic Development and Trade of Ukraine corporate website. URL: http://me.gov.ua/Documents/ List?lang =uk-UA\&id=e384c5a7-6533-4ab6-b56f50e5243eb15a\&tag (accessed 8 April 2019).

\section{UDC 332.324: 330.101.541}

\section{THE CORPORATE SECTOR AS A SOURCE OF ECONOMIC GROWTH IN UKRAINE \\ Oksana Taranych}

\author{
Vasyl’ Stus Donetsk National University, Vinnytsia, Ukraine
}

\begin{abstract}
Summary. The paper considers the features of the corporate sector development as a source of Ukraine's economic growth in connection with the necessity for expanded reproduction and reconstruction of the national industry, the ways and methods of attracting targeted investments in the conditions of the systemic financial and political crisis are determined. The purpose of the article is to define approaches to the development of the corporate sector in Ukraine. It has been determined that excessive concentration of capital (oligarchization), corruption and non-transparency of state enterprises management determine the discouragement of industry and consumer sector development in Ukrainian economy. The result is disproportional number of the middle class and a significant level of the shadow economy. The mechanism of shadow reconstruction funds for innovative corporate sector is an important social and political challenge to government. An overview of the features of the corporate sector of Ukraine development implemented and determined that the depreciation of fixed assets and the structure of production did not reach the requirements to produce competitive products on the world market. Depreciation of fixed assets is practically prevented develop the production of high-tech products; excessive energy efficiency blocks profits for their recovery. Several conditions concerning the reproductive development of the corporate sector related to the integration of bank capital, specialized research institutes, the development of mechanisms of public-private partnership and subcontracting proved. The purposeful approaches to the development of the corporate sector in Ukraine, related to the privatization of machine-building enterprises through the restoration of fixed assets and measures aimed to reduce the level of the shadow economy, to produce products for import substitution and high-tech exports and integration of the country's banking sector with the corporate sector and the global financial market are determined.
\end{abstract}

Key words: corporate sector, economic growth, international competitiveness of enterprises, privatization, corporatization, innovations, technological practices, stock market. 